Ю.О. Фтемов

Наџіональна академія сухопутних військ ім. гетьмана П. Сагайдачного, Львів

\title{
РЕКОМЕНДАЦІЇ З ПРИКРИТТЯ МІЖПОЗИЦІЙНОГО ПРОСТОРУ ІЗ УРАХУВАННЯМ ЗАХОДІВ ЗАВЧАСНОЇ ПІДГОТОВКИ ТЕРИТОРІЇ ДО ОБОРОНИ
}

У статті проведено аналіз сучасного характеру і спрямованості оперативної та бойової підготовки противника, ймовірних способів ведення наступальних бойових дій з подоланням інженерних загороджень, а також тенденції розвитку засобів інженерного озброєння з підтримання мобільності підрозділів, в умовах влаштування масових загороджень та здійснення руйнувань. Обтрунтовано і надано рекомендації щзоо прикриття міжпозиційного простору з урахуванням заходів завчасної підготовки території до створення системи інженерних загороджень в ході оборонного бою (операціï).

Ключові слова: система інженерних загороджень, мінно-вибухові загородження, міжпозиційний простір, завчасна підготовка, оборона, ефективність інженерних загороджень.

\section{Вступ}

Постановка проблеми. Динамічні зміни в способах ведення бойових дій військ (сил) у ході збройних конфліктів, міжнародних операцій з підтримання миру і безпеки висувають нові, більш високі вимоги до виконання завдань інженерного забезпечення, розширюють їх зміст, вимагають удосконалення способів і прийомів їх виконання, а також розширюють та ускладнюють роботу командира підрозділу щодо прийняття рішення на бойове застосування наявних сил і засобів для виконання завдань інженерного забезпечення.

Досвід локальних війн і збройних конфліктів останніх років свідчить про значні зміни в теорії інженерного забезпечення сучасних бойових дій. Окреме місце при цьому займає створення системи інженерних загороджень (СI3), яка в побудові оборони є одним із важливих їі елементів. Слід зазначити, що роль і вагомість СІ3 в сучасних умовах постійно зростає. Це також обумовлено невідповідністю просторового розмаху ведення бойових дій і наявними силами (засобами), що приймають в ній участь, а також невідповідністю обсягів завдань із створення СІ3 до можливостей військ.

Підтвердженням зазначеного $є$ те, що фактично усі підрозділи ООС, які виконують бойові завдання уздовж лінії розмежування сторін, утримують райони оборони (опорні пункти), розміри яких по фронту i вглибину значно перевищують нормативні показники. Це спричинено не тільки наявністю сил і засобів, а й можливостями противника та фізикогеографічними умовами місцевості, що у свою чергу значно ускладнює здійснення заходів дієвого контролю за визначеною зоною відповідальності.
Аналіз останніх досліджень і публікацій. Вивчаючи джерела у яких започатковано вирішення даної проблеми і на які опирається автор, свідчить що питання прикриття міжпозиційного простору 3 урахуванням заходів завчасної підготовки території до улаштування загороджень, в керівних документах, розкрито не в повному обсязі, що у свою чергу спонукає до опрацювання науково-методичних розробок та відповідних рекомендацій.

Наявний науково-методичний апарат базується на положеннях, які розробляли: В. Лісневський, О. Мацько, В. Коцюруба, М. Підгородецький, М. Івасюк, І. Черних, С. Цибуля, Я. Кізяк, В. Телелим, В. Кириленко та безумовно враховує загрози, форми та способи виконання поставлених завдань відповідним підрозділам. Разом з тим наукові результати зазначених досліджень не у повній мірі можуть бути адаптовані до умов сьогодення [1-5].

Мета статті. На основі аналізу можливого характеру та способів ведення бойових дій противника, застосування СІ3 на підставі набутого раніше досвіду, обгрунтування видів, обсягів інженерних загороджень, метою статті $є$ вироблення рекомендацій 3 їх удосконалення у загальній системі виконання завдань інженерного забезпечення бойових дій 3 визначенням умов проведення завчасних підготовчих заходів території держави до оборони.

\section{Виклад основного матеріалу}

Характер ведення сучасної оборонної операції (бою) свідчить про перехід від теорії “оборони районів”, яка була характерна в роки “холодної війни” до теорії мобільної та маневреної оборони. Враховуючи те, що частини та підрозділи Збройних Сил (3С) України виконують бойові завдання на Сході України цілком зрозумілим, що досвід інженерного 
забезпечення підготовки й ведення бойових дій у воєнних конфліктах, зокрема питання створення СI3 набуває особливого значення на сучасному етапі розвитку українського війська [6].

Значні зміни відбулися в поглядах на характер та способи ведення можливих у майбутньому війн, що в свою чергу викликало зміну поглядів на форми та способи ведення бою. Концепція глибокого вогневого ураження перейшла у розробку і проведення “об’єднаних операцій”.

Характерними формами воєнних дій у сучасних умовах стають: далекий дуельний вогневий бій; груповий бій з нанесенням групових та масованих ударів комплексними системами; бойові дії загальновійськового характеру та дії одного виду (роду) військ шляхом нанесення масованих (групових) ударів чи методичного впливу, операції самостійного та загальновійськового характеру. Можливості новітньої зброї дозволяють по-новому реалізовувати принципи активності, рішучості та безперервності ведення бойових дій [7]. Для цього можуть бути застосовані, як різні засоби, так і різні об'єкти впливу. Виходячи 3 цього можна зробити висновок, що поле бою в майбутньому буде характеризуватися меншою щільністю сил і засобів і великим просторовим розмахом.

Сутність концепції “об’єднаних операцій” полягає у високоманеврених та в першу чергу, наступальних діях батальйонних тактичних груп (БТГр) бригад та бойової авіації, що проводяться 3 метою одночасного та гарантованого знищення противника на всю глибину оперативної побудови його військ. Вона припускає початкове розосередження своїх військ, щоб виключити їхню поразку далекобійними засобами. Потім нанесення потужного вогневого ураження важливих об'єктів противника чи районів розташування його угруповань, після чого, використовуючи перевагу, що створилася, частини і з'єднання швидко виходять на обраний напрямок і завершують розгром конфронтуючих формувань у ближньому бою. У подальшому вони знову розосереджуються для відновлення боєздатності і підготовки до нових бойових дій.

Аналіз досліджень [2; 6-7], показує що на етапі вирішальних бойових дій противник, як правило, буде переходити в наступ з висуванням із глибини. Цей спосіб характеризується тим, що ударне угруповання висувається з глибини на рубіж переходу в атаку, розгортається в бойовий порядок і без зупинки переходить у наступ. Наступ з ходу буде вестися безпосередньо 3 пунктів постійної дислокації чи районів зосередження, що будуть знаходитися на видаленні 30-80 км від державного кордону або переднього краю (лінії зіткнення). При цьому найбільш складними умовами для наступу визначаються такі, коли перед військами, що обороняються, $є$ смуга забезпечення. Підрозділи в цьому випадку будуть висуватися для наступу в послідовності, аналогічній маршу. Попереду будуть висуватися війська прикриття (передові загони). Роль військ прикриття будуть виконувати розвідувальні батальйони та БТГр - від бригад першого ешелону. Вони посилюються артилерійськими, інженерними, танковими підрозділами, у ході виконання завдання - підтримуються бойовою авіацією.

Успішне ведення противником наступальних бойових дій забезпечується своєчасною доставкою на поле бою підрозділів, бойової техніки і матеріально-технічних засобів, а також інженерним забезпеченням подолання ними перешкод і загороджень, тобто забезпечення мобільності військ. Для вирішення цього завдання будуть залучатись значні сили не тільки інженерних, але й інших родів військ. Тому комплекс завдань з мобільності військ буде включати: протимінну боротьбу; розвідку мінних полів (МП), влаштування в них проходів; позначення МП і їх розмінування; подолання перешкод застосування засобів інженерного озброєння для влаштування мостових переходів через перешкоди та пророблення проходів в інженерних загородженнях або обладнання обходів; форсування водних перешкод; підготовку та утримання доріг і колонних шляхів [6-9].

В окремих випадках, коли вирішальне значення приділяється підтриманню темпу наступу і термінам пророблення проходів, МВ3 можуть долатися 3 ходу, тобто “на ризик” [10-12]. У залежності від конкретної бойової обстановки, наявності сил і часу може здійснюватися прискорене або планомірне подолання мінно-вибухових загороджень (МВ3). Разом 3 тим, вибір того чи іншого способу подолання СІ3 буде залежати від ряду факторів, основними 3 який $€$ : поставлене бойове завдання, наявність сил, засобів і часу; дані про інженерні загородження, у тому числі - ступінь прикриття їх вогнем оборони; характер рельєфу місцевості; метеорологічні умови; наявність вогневої підтримки підрозділів, що наступають та долають загородження.

При цьому прийнято вважати, що прискорене подолання МВ3 передбачається здійснювати в умовах безпосереднього вогневого впливу оборони, при відсутності часу на розвідку або на планомірне подолання СI3 [5; 12].

Для забезпечення подолання інженерних загороджень БТГр першого ешелону передбачається їхнє підсилення інженерними підрозділами. При наступі бригади на головному напрямку, їй додатково може бути виділена інженерно-саперна рота (рота розгородження) вищого підпорядкування і виділяється резерв у складі до інженерного взводу [4-7].

В ході наступу з планомірною підготовкою для подолання інженерних загороджень у кожній БТГр 
створюються: група вогневої підтримки, у завдання якої входить придушення вогню противника, що прикриває загородження, прикриття дій групи розгородження димами; підгрупа розгородження у складі взводу інженерних військ (IB), посиленого спеціальною інженерною технікою 3 завданням влаштування проходів у МВ3 та обладнання переходів через невибухові загородження (НВ3) [5; 6-8]. Вважається, що при такому підсиленні БТГр першого ешелону бригади в змозі долати інженерні загородження противника.

Таким чином, проведений аналіз показує, що бойові дії розгортаються одночасно перед фронтом, на флангах, у тилу протидіючих військ, на землі й у повітрі. Наступаючі війська будуть виконувати свої завдання шляхом нанесення головним силам військ, що обороняються, максимальних втрат за рахунок масованого застосування високоточної зброї на всю глибину побудови бойового порядку. При цьому мета бою буде досягатися комплексним застосуванням усіх засобів збройної боротьби - авіації, ракетних військ, артилерії (РВіА) і радіоелектронної боротьби, підрозділів родів військ і спеціальних військ. Для проведення наступальних операцій противник буде створювати співвідношення сил на свою користь 4:1-5:1, при подоланні МВ3 застосовувати подовжені заряди розмінування та мінні трали, а для подолання НВ3 та існуючих перешкод інженерні машини, саперні танки та мости супроводження.

Безпекова ситуація в Україні та навколо неї продовжує визначатися агресивною зовнішньою політикою Російської Федерації. Аналіз воєннополітичної та воєнно-стратегічної обстановки свідчить про високу ймовірність швидкоплинного загострення ситуації [13].

Впродовж 2015 та 2016 років дії російських регулярних підрозділів на окупованих територіях Луганської та Донецької областей України були активними і загалом мали ознаки підготовки до більш масштабних наступальних дій. При цьому використовувалася тактика дій “мобільними ударними групами”. Використовуючи “тактику обходу” та уникаючи контактних боїв, пізніше противник перейшов до “неконтактної війни” - силами розвідки, з метою виявлення бойових порядків українських підрозділів і нанесення їм вогневого ураження далекобійними артилерійськими засобами. Схожу тактику “кочівних танкових груп”, “кочівних вогневих точок” перейняли і використовували бойовики НЗФ так званих “армій ЛДНР”.

Тому, заплановані раніше наступальні дії противника змінилися на штурмові дії в окремих районах 3 конкретною метою продовжувати гібридну війну на виснаження сил (АТО) ООС, підірвати боєздатність конкретних бойових частин і підрозділів та порушити стійкість оборони українських військ.

Іншими особливостями тактики штурмових дій противника було одночасне їх проведення в різних місцях, щоб не допустити маневру сил українською стороною і змусити іiі витрати максимальну кількість резервів по всій лінії фронту. Проте окремі штурмові дії противника були лише імітацією для маскування підготовки штурмових ударів на головних напрямках.

Проводячи аналіз сучасного характеру і спрямованості оперативної та бойової підготовки ЗС Російської Федерації [14] можна зробити висновки, що основні зусилля 3 організації і проведенні цих заходів спрямовані на:

- підготовку до ведення наступальних операцій (бойових дій);

- створення та застосування міжвидових (різнорідних) угруповань, оперативне перекидання їх на великі відстані;

- здійснення перевірок тактико-технічних характеристик новітніх зразків озброєння і військової техніки та випробування їх безпосередньо в бойових умовах (на окупованих територіях сходу України);

- збільшення кількості тактичних навчань 3 наступальної тематики (у т.ч. в нічний час), підготовки до ведення бойових дій у населених пунктах та виконання бойових завдань на незнайомій місцевості та ін. [13-14].

Слід зазначити, досліджуючи умови підготовки і ведення сучасних операцій можна зробити висновок, що основними напрямками розвитку IB 3С Російської Федерації на найближчу перспективу будуть: зростання ролі інженерного забезпечення та збільшення обсягу завдань в обороні $25 \ldots 30 \%$, в наступі $30 \ldots 45 \%$; збільшення вимог, стосовно самостійного виконання завдань загальновійськовими підрозділами, за рахунок зростання можливостей 3 виконання завдань інженерного забезпечення від 20 до 40\% [13-14].

Також, з метою підтримання мобільності підрозділів під час проведення наступальних операцій, в умовах влаштування масових загороджень та здійснення руйнувань, на замовлення IB ЗС Російської Федерації, науковими установами передбачається створення:

- наземно-повітряних комплексних засобів інженерної розвідки багатоцільового призначення 3 можливостями автоматизованого обробленням інформації та передачі іï до автоматизованої системи управління військами в умовах реального часу, що забезпечує дистанційне виявлення мін, визначення прохідності місцевості, iї захисних властивостей, а також удосконалення переносних міношукачів;

- перспективних роботизованих засобів пошуку і знищення вибухонебезпечних предметів, в т.ч. у міських умовах; 
- інженерної системи дистанційного мінування (СДМ), розвідувально-тралового (роботизованого) комплексу для ефективного вирішення завдань 3 подолання МП великої глибини, засобів суцільного розмінування місцевості, а також удосконалення мінних тралів і неконтактних засобів тралення [15].

Виходячи із зазначеного можна стверджувати, що ЗС Російської Федерації здійснюють планомірні заходи до проведення наступальних операцій (бойових дій). 3 метою створення необхідних умов 3 підтримання мобільності загальновійськових підрозділів будуть широкого застосовані, як сучасні, так i перспективні засоби інженерного озброєння.

Тому для відбиття агресії в залежності від обстановки на різних напрямках у перших і подальших операціях початкового періоду війни може застосовуватися в різних сполученнях позиційна і маневрена оборона.

За сучасними поглядами військових фахівців [1; 4; 6-8] оборона - це, насамперед, боротьба з бойовими броньованими машинами. За їх думкою, рекомендується певну увагу приділяти правильному вибору місцевості та максимальному використанню iii захисних властивостей для підвищення стійкості протитанкової оборони, комплексному застосуванню засобів боротьби з танками та їх глибокому ешелонуванню, створенню ефективної системи протитанкового вогню, широкому застосуванню інженерних загороджень, основу яких складають мінновибухові.

Бойові дії, які ведуться у більшості воєнних конфліктах сучасності, (АТО) ООС, переконливо свідчать, що у питаннях інженерного забезпечення дій військ (сил) відмічається стійка тенденція до зміни пріоритетності заходів різнорідного характеру порівняно з класичними підходами.

Отже, до основних особливостей ведення бойових дій в зоні проведення (АТО) ООС, слід віднести збільшення міжпозиційного простору між опорними пунктами і районами оборони.

Шляхами вирішенням даного питання $є$ надання рекомендацій із “закриття" цих проміжків, яке буде здійснюватися шляхом:

- чіткого розподілу меж і зон відповідальності між підрозділами, що обороняються;

- широкого використання сигнальних засобів (мін);

- завчасного улаштування інженерних загороджень 3 ефектами повороту і блокування підрозділів противника, з обов'язковим прикриттям загороджень усіма видами вогню;

- визначення зон 3 обмеженим використанням загороджень для здійснення маневру силами і засобами у т.ч. інженерними; застосування несиметричної зовнішньої смуги МВ3;

- створення системи спостереження і коригу- вання вогню, у т.ч. $з$ використанням технічних засобів ведення розвідки, БПЛА та ін.;

- створення загороджувального вогню підрозділами РВіА по визначених ділянках (рубежах) із урахуванням влаштованих МВ3;

- улаштування інженерних загороджень із застосуванням різноманітних СДМ;

- створення зведених бойових (штурмових) мобільних груп (загонів) з включенням до їх складу підрозділів IB.

Як зазначалося, СІ3 має за мету скувати дії противника і нанести ураження живій силі та техніці противника інженерними боєприпасами (ІБП), створити умови для підвищення ефективності всіх вогневих засобів своїх військ, утруднити мобільність військ противника і знизити темпи його просування. Ретельно розраховані, сплановані, якісно улаштуванні та документально зафіксовані окремі складові СІ3 забезпечують підвищення іiі ефективності в цілому. Однак, на сьогоднішній день спостерігається тенденція зі скорочення номенклатури ІБП, що у свою чергу має значний вплив на створення СI3 в умовах обмеженого часу [16].

Враховуючи обмеженість у силах та засобах, улаштування загороджень повинно починатися ще у мирний час у рамках завчасної підготовки території держави. Деякі з традиційних загороджень підготовлюються реально, а інші можуть тільки включатися у плани підготовки, намічатися на картах 3 подальшим уточненням на місцевості.

Завчасна підготовка до улаштування загороджень повинна здійснюватися скритно, деякі заходи доцільно проводити під виглядом та у комплексі 3 народногосподарськими роботами при досить обмеженій інформації.

Проведені дослідження заходів мирного часу 3 підготовки театру воєнних дій показують, що для створення більш ефективної СІ3 у короткий період часу з необхідною щільністю, доцільно здійснювати ряд організаційних і підготовчих заходів.

До основних організаційних заходів відносяться:

- створення карти інженерної оцінки місцевості 3 додатком матеріалів рекогносцировки запланованих загороджень і прогнозом мінної обстановки, загороджень у смузі оборони;

- створення груп рекогносцировки спільно 3 органами Державної прикордонної служби України (ДПСУ);

- поділ об'єктів, що готуються до руйнування і загороджень за категоріями і ступенем важливості, 3 визначенням трьох ступенів готовності для цих об'єктів;

- організація взаємодії з органами ДПСУ, дорожньо-експлуатаційними, будівельними організаціями 3 питань обладнання об'єктів дорожньо- 
гідрографічної мережі необхідними пристосуваннями для закладки вибухових речовин (зарядів) на випадок виходу їх з ладу;

- проведення спільних з органами ДПСУ рекогносцирувань запланованих районів ведення бойових дій підрозділами бригад 3 метою виявлення районів вільних від мін, районів (ділянок) запланованого улаштування мінних полів (МП) і керованих МП, що прив'язані до рубежів контратак, районів установлення МП засобами дистанційного мінування.

Підготовчі заходи включатимуть:

- залучення підрозділів органів ДПСУ до заходів інженерної підготовки операційного району для створення системи загороджень;

- підготовка матеріально-технічної бази для об'єктів, що готуються до руйнування, іiі зосередження на складах частин, що виконують завдання по підготовці об'єктів, з метою створення загороджень;

- завчасна інженерна підготовка об’єктів 3 метою їх руйнування (вироблення зарядних камер, ніш, галерей, шурфів, колодязів, вказівка місць кріплення зарядів, улаштування підривних станцій);

- підготовка польових складів ІБП і шляхів руху до об'єктів загороджень і складів ІБП;

- підготовка до руйнування залізничних і автомобільних доріг; підготовка до руйнування гідротехнічних споруд, гребель, водосховищ для створення зон затоплень, їх розрахунок;

- підготовка до руйнування залізничних станцій і підприємств місцевої промислової бази;

- підготовка до руйнування аеродромів;
- підготовка до руйнування і улаштування ескарпів (контрескарпів), протитанкових ровів;

- підготовка і розрахунок вузлів загороджень на дорожніх напрямках та смуг загороджень;

- улаштування невибухових протитанкових i протипіхотних загороджень.

\section{Висновки}

Таким чином, виконання комплексу заходів із завчасної підготовки до руйнувань на дорожніх напрямках дають змогу підвищити ефективність виконання завдання по влаштуванню інженерних загороджень на $10 \ldots 15 \%$ за рахунок скорочення обсягу робіт в загрозливий період, тим самим підвищується ефективність СІЗ.

Отримані результати дають підстави для внесення ряду змін і доповнень до існуючих керівних документів, що регламентують основи завчасної підготовки території держави до відсічі збройної агресії.

Однак, на сьогоднішній день спірність, невизначеність ряду положень, суттєві зміни в розвитку збройних сил, формах і способах застосування військ (сил) у сучасних умовах викликають необхідність подальшого дослідження питання підвищення ефективності СІЗ.

Враховуючи те, що основою СІ3 є МВ3, однак, зменшення номенклатури ІБП та відсутність їх перспективних зразків мають значний вплив на ії створення та ефективність в цілому. Тому, на найближчу перспективу слід визначити напрями розвитку ІБП.

Саме розгляд цих питань обумовлюють спрямування подальших досліджень.

\section{Список літератури}

1. Телелим В.М. Рекомендації управлінню органу охорони державного кордону щодо застосування прикордонних підрозділів швидкого реагування при загостренні воєнно-політичної обстановки [Електронний ресурс] / В.М. Телелим, В.А. Кириленко, В.І. Лемешко // Збірник наукових праць Національної академії державної прикордонної служби України. - 2017. - № 2(72). - С. 196-210. - Режим доступу: http://surl.li/hxna.

2. Ткаченко М.Д. Послідовність та зміст роботи командира і штабу з'єднання щодо організації маневреної оборони / М.Д. Ткаченко, М.А. Павленко // Збірник наукових праць Харківського університету Повітряних Сил ім. І. Кожедуба. 2008. - № 2(17). - С. 29-32. - Режим доступу: http://www.hups.mil.gov.ua/periodic-app/article/3783/zhups_2008_2_10.pdf.

3. Серватюк В.М. Аналіз шляхів підвищення ефективності застосування інженерних загороджень для прикриття державного кордону / В.М. Серватюк, Р.А. Миколайчук, С.В. Мальченко // Збірник наукових праць Національної академії державної прикордонної служби України. - 2008. - № 2(44). - С. 26-28.

4. Черних І.В. Особливості інженерного забезпечення за досвідом сучасних локальних війн і збройних конфліктів / I.В. Черних, В.І. Коцюруба // Збірник наукових праць “Труди академіі”. - 2004. - № 56. - С. 207-216.

5. Мацько О.Й. Шляхи підвищення ефективності виконання завдань 3 подолання загороджень / О.Й. Мацько // Збірник наукових праць “Труди академії”. - 2000. - № 21. - С. 111-114.

6. Нещадін О.В. Інженерне забезпечення бою в сучасних операціях / О.В. Нещадін, О.Й. Мацько, Ю.О. Фтемов. Львів: НАСВ, 2017. - 320 с.

7. Чугуй Г.Є. Погляди воєнного керівництва провідних держав світу на ведення наступальних операцій і роль маневру у них / Г.С. Чугуй, Ю.П. Переверзін // Збірник наукових праць “Труди академії”. - 2002. - № 15. - С. 51-55.

8. Настанова з інженерного забезпечення Збройних Сил України. - К.: ГШ ЗСУ, 2010. - 168 с.

9. Бамбуляк М.П. Улаштування інженерних загороджень в особливих умовах / М.П. Бамбуляк, Ю.О. Фтемов, Р.Л. Колос // Системи озброєння і військова техніка. - 2014. - № 1(37). - С. 2-4. - Режим доступу: http://www.hups.mil.gov.ua/periodic-app/article/2305/soivt_2014_1_3.pdf.

10. Фтемов Ю.О. Перспективи розвитку засобів забезпечення мобільності / Ю.О. Фтемов, О.В. Нещадін // Збірник 
тез доповідей Міжнародної науково-технічної конференції “Перспективи розвитку озброєння та військової техніки сухопутних військ”. - Львів, 17-18 травня 2019 р. - С. 316-317.

11. Фтемов Ю.О. Ефекти мінних полів / Ю.О. Фтемов // Збірник тез доповідей науково-технічної конференції “Перспективи розвитку озброєння та військової техніки сухопутних військ”. - Львів, 14-15 травня 2018 р. - 158 с.

12. Фтемов Ю.О. Влаштування загороджень для прикриття міжпозиційних проміжків / Ю.О. Фтемов, Р.Л. Колос // Збірник тез доповідей Міжнародної науково-технічної конференції “Перспективи розвитку озброєння та військової техніки сухопутних військ". - Львів, 17-18 травня 2019 р. - 315 с.

13. Уроки “гібридної війни": Воєнні аспекти // Збірник матеріалів науково-практичної конференції. Ч. І. - К.: ГШ 3СУ. $-2016 .-189 \mathrm{c}$.

14. Інформаційний бюлетень. Вип. І. - К.: НДІ ГУР МОУ. - 2016. - 151 с.

15. Инженерные войска Вооруженных Сил Российской Федерации и основы их боевого применения / Д.В. Шуняков, К.С. Фокин, Ю.Ф. Куприянов, И.А. Донченко, В.А. Батмазов. - Екатеринбург: Изд. Уральского университета. 2017. - 118 c. - Режим доступу: http://surl.li/hxpv.

16. Фтемов Ю.О. Способи підвищення бойових можливостей інженерних боєприпасів / Ю.О. Фтемов, Р.Л. Колос, В.П. Павлючик // Військово-технічний збірник Національної академії сухопутних військ ім. гетьмана П. Сагайдачного. 2016. - № 15. - С. 58-62. - Режим доступу: - http://nbuv.gov.ua/UJRN/vtzb_2016_15_13.

Надійшла до редколегії 02.11.2020

Схвалена до друку 01.12.2020

\section{Відомості про автора:}

\section{Фтемов Юрій Олександрович}

кандидат технічних наук старший науковий співробітник доцент Національної академії сухопутних військ ім. гетьмана П. Сагайдачного, Львів, Україна https://orcid.org/0000-0003-1709-5395

\section{Information about the author:}

\section{Yuriy Ftemov}

Candidate of Technical Sciences Senior Research

Senior Lecturer

of Hetman Petro Sahaidachnyi National Army Academy, Lviv, Ukraine

https://orcid.org/0000-0003-1709-5395

\title{
РЕКОМЕНДАЦИИ ПО ПРИКРЫТИЮ МЕЖПОЗИЦИОННОГО ПРОСТРАНСТВА С УЧЕТОМ МЕР ЗАБЛАГОВРЕМЕННОЙ ПОДГОТОВКИ ТЕРРИТОРИИ К ОБОРОНЕ
}

Ю.А. Фтемов

В статье проведен анализ современного характера и направленности оперативной и боевой подготовки противника, вероятных способов ведения наступательных боевых действий с преодолением инженерных заграждений, а также тенденции развития средств инженерного вооружения по поддержанию мобильности подразделений, в условиях устройства массовых заграждений и осуществления разрушений. Обоснованы и даны рекомендации по прикрытию межпозиционного пространства с учетом мер заблаговременной подготовки территории к созданию инженерных заграждений в ходе оборонительного боя (операции).

Ключевые слова: система инженерных заграждений, минно-взрывные заграждения, межпозиционное пространство, заблаговременная подготовка, оборона, эффективность инженерных заграждений.

\section{RECOMMENDATIONS FOR COVERING THE INTERPOSITION SPACE, TAKING INTO ACCOUNT MEASURES FOR EARLY PREPARATION OF THE TERRITORY FOR DEFENSE}

\author{
Yu. Ftemov
}

The experience of local wars and armed conflicts in recent years shows significant changes in the theory of engineering support of modern hostilities. This is due to the inconsistency of the spatial scope of hostilities and the available forces (means) participating in it, as well as the inconsistency of the scope of tasks to create a system of engineering barriers to the capabilities of troops (forces). Therefore, the purpose of the article is to develop recommendations for covering the interposition space, taking into account measures for early preparation of the territory for defense, and the subject of the study is to increase the efficiency of the system of engineering barriers. The article analyzes the current nature and direction of operational and combat training of the enemy, the probable methods of offensive combat operations to overcome engineering barriers, as well as trends in the development of engineering weapons to maintain unit mobility, in the conditions of mass barriers and destruction. Based on the analysis of the possible nature and methods of combat operations of the enemy, the use of engineering barriers on the basis of previous experience, justification of types, volumes of engineering barriers, developed recommendations for covering the interposition space taking into account measures to prepare the territory operations). Thus, the implementation of a set of measures for early preparation for destruction on roads allows to increase the efficiency of the task of installing engineering barriers by $10 \ldots 15 \%$ by reducing the amount of work in the threatening period, thereby increasing the efficiency of the engineering barriers. The obtained results give grounds for making a number of changes and additions to the existing guiding documents regulating the basics of early preparation of the territory of the state to repel armed aggression.

Keywords: system of engineering barriers, minefields, interpositional space, early training, defense, efficiency of engineering barriers. 